\title{
Effect of surgical stress on Serum cholesterol level
}

\author{
Verma LP' ${ }^{1}$, Dutt $C^{2}$, Dutt RD ${ }^{3}$ \\ ${ }^{1}$ Dr. LP Verma, MS, FAIS (Surgery), Ph D, Dean, Bundelkhand Medical College, Sagar, MP, India, ${ }^{2}$ Dr. (Mrs.) \\ Chandrakala Dutt, MS (Surgery), Assistant Professor, Department of Surgery, JA. Group of Hospitals \& Kamla Raja \\ Hospital, G R Medical College, Gwalior, MP, India. ${ }^{3}$ Dr R.D. Dutt, M.D. (Pediatrics), PGDDN, Developmental \\ Neurology, Associate Professor, Department of Pediatrics Bundelkhand Medical College, Sagar, M.P, India.
}

Address for Correspondence: Dr. R.D. Dutt, 112, Tansen Nagar, Gwalior, MP, Email - dr $\underline{\text { rddutt@ rediffmail.com. }}$

\begin{abstract}
Introduction: Stress in the Biological sense is the interaction between damage \& defense. Anything that causes stress endangers life unless it is counteracted by adequate adoptive response. Conversely anything endangers life causes stress and adaptive responses. Adaptability and resistance to stress are fundamental requisites for life and very vital organ and function participate in them. Aims: To assess the preoperative value of serum cholesterol in different elective surgical operations. Methodology: In study 40 normal subjects were taken for serum cholesterol estimation. Serum cholesterol was estimated in 100 patients who were taken for various surgeries in respect of age, sex, and social status. The patients were categorized under three groups, group A - patient who underwent operation lasting for $1 / 2$ an hour or less, group B those with operations lasting between half an hour to $1 \frac{1 / 2}{2}$ hour, group $\mathrm{C}$ - operations lasting for more than $1 \frac{1}{2}$ hour. Results: Serum cholesterol value in normal healthy individuals was ranged from 124 to 240 . Serum cholesterol level falls to its maximum on the first postoperative day in all cases of group A, B and C except 3 cases in group $\mathrm{C}$ in which maximum fall was observed on 3rd postoperative day. Conclusion: The more the surgical stress slower was the recovery.
\end{abstract}

Keywords: Cholesterol standard, colour reagent, ferric chloride, glacid acetic acid.

\section{Introduction}

Stress in the Biological sense is the interaction between damage \& defense. Anything that causes stress endangers life unless it is counteracted by adequate adoptive response. Conversely anything endangers life causes stress and adaptive responses. Adaptability and resistance to stress are fundamental requisites for life and very vital organ and function participate in them.

Stress includes variety of adverse condition, which tends to harm the organism. Stress may develop sunddenly and be short lasting or develop very long time or it may be overwhelming, ending in death. The effect may be mild or severe, they may develop quickly or gradually and may be short lasting or prolonged depending upon the type of stress.

Manuscript received: ${ }^{1 \text { st }}$ Sept 2015

Reviewed: $10^{\text {th }}$ Sept 2015

Author Corrected: $24^{\text {th }}$ Sept 2015

Accepted for Publication: $1^{\text {st }}$ Oct 2015
Surgical stress is the combination of nervous and traumatic stress enhanced by bleeding, handling of viscera, shock and anesthesia. The surgical stress appears to be one of the most important facts disturbing the 'mileu inferior'.

Surgical operation on an individual is paramount to trauma willfully inflicted on an individual. The response of the body to this kind of stress is more or less akin to the metabolic response after an injury to the body. This type of reaction is a normal physiological process.

Release of ACTH during stress was found to be associated with decrease in the Serum Cholesterol (Kyle, Hess, Walsh, 1996) demonstrating a close relation between the serum cholesterol levels and stress. 
Through some unknown pathway, a stimulus travels from the site of injury or area of surgical operation to the anterior pituitary. The pituitary and hypothalamus are simulated in the condition of stress and discharge of ACTH and somatotrophic hormone is thus begun. Somatotrophic hormone acts directly on tissues while called as pro-phogistic corticoids (PC) and glococoticoids also called as antiphologistic corticoids (AC).

Cholesterol is present in blood plasma of human beings in two forms partly in the two forms partly in the free state and partly esterified with fatty acids. These being respectively known as "free cholesterol" and "ester cholesterol" which together forms total cholesterol content.

In the blood plasma of normal persons cholesterol level varies from $150-250 \mathrm{mg}$. Per $100 \mathrm{ml}$. of this $60-80 \%$ is present in the esterified form and $20-40 \%$ exists in the free fraction. Cholesterol or its esters are present in cytoplasm of all the cells and the word derives its name form "Chole-bile", "Sterol - solid" - bile being the rich source.

ACTH, which is through to be released in increased amount during stress has been shown in normal persons to be associated with a marked depression of serum Cholesterol (Kyle, Hess, Walsh, 2002).

S. Cholesterol \& surgical stress are closely related to each other.

The association between the two variables has been shown in many studies conducted in the past. These studies have shown a declined in the S. Cholesterol level with the surgical stress in an individual. We have also conducted a study in patients admitted in surgical wards of J.A. Hospital Gwalior \& S. Cholesterol level was measured in relation to the duration of surgical stress. Inference were drawn which were significant \& were outline in the conclusion of this thesis.

\section{Aims \& Objective}

1. To assess serum Cholesterol concentration in normal healthy individual.

2. To assess the preoperative values of Serum Cholesterol in different elective surgical operation.

3. To determine variations in the level of Serum Cholesterol in post operative period in -patient undergoing elective surgery.

\section{Material and Methods}

The present work is based on the investigations (Serum Cholesterol) carried out on the patients admitted in surgical wards of J.A. Group of Hospitals, Gwalior(MP). 100 patients were selected from the admissions to the surgical service. No patients were included for study if significant complicating diseases were detected by history, physical examination or laboratory tests.

The patients were categorized under three groups:

Group 'A' - Including patients who underwent operation lasting for $1 / 2$ an hour or less.

Group 'B' - Those with operation lasting between half an hour to $1 \frac{1}{2}$ hour.

Group ' $\mathrm{C}$ ' - Comprising patients with operations lasting for more than $1 \frac{1 / 2}{2}$ hour.

Selection of Normal: Prior to the study of the patients, estimations were done in normal individuals, males and females to establish the normal Serum Cholesterol level.

Principle: The cholesterol is estimated by means of a modified "Liberman-Burchard" reaction. This comprises of the production of a red colour when acetic acid solution of certain sterols is treated with ferric chloride and sulphuric acie (Zhatkis, Zak and Boyle, 1997). 


\section{Results}

Table No. 1: For average normal values of S. Cholesterol in mgm. \% in different age groups

\begin{tabular}{|l|l|l|l|l|}
\hline Sr. No. & Age in years & NO. of Cases & Range & $\begin{array}{l}\text { Average values of S. } \\
\text { Cholesterol in mgm \% }\end{array}$ \\
\hline 1. & $0-12$ years & 11 & $125-159$ & 146 \\
\hline 2. & $13-20$ years & 2 & $155-185$ & 167 \\
\hline 3. & $21-30$ years & 15 & $163-217$ & 186 \\
\hline 4. & $31-40$ years & 3 & $185-213$ & 201 \\
\hline 5. & $41-50$ years & 7 & $203-241$ & 216 \\
\hline 6. & 51 and above & 2 & $211-223$ & 217 \\
\hline
\end{tabular}

The highest average value of S. Cholesterol $217 \mathrm{mg} . \%$ were observed in individuals above 51 years of age while the lowest value (146 were observed in the $1^{\text {st }}$ age group up to 12 years.

Table No. 2: Showing Average Normal Value of Serum Cholesterol in Sex Groups

\begin{tabular}{|l|l|l|l|l|l|}
\hline Sr. No. & Age Group & Male & Female \\
\hline & & No. of cases & $\begin{array}{l}\text { Average S. Cholesterol in } \\
\text { mg \% }\end{array}$ & $\begin{array}{l}\text { No. of } \\
\text { cases }\end{array}$ & $\begin{array}{l}\text { Average S. Cholesterol } \\
\text { in mgm.\% }\end{array}$ \\
\hline 1. & $0-12 \mathrm{yrs}$ & 8 & 142 & 3 & 151 \\
\hline 2. & $13-20 \mathrm{yrs}$ & 1 & 160 & 1 & 170 \\
\hline 3. & $21-30 \mathrm{yrs}$ & 7 & 195 & 8 & 176 \\
\hline 4. & $31-40 \mathrm{yrs}$ & 2 & 212 & 1 & 192 \\
\hline 5. & $41-50 \mathrm{yrs}$ & 5 & 227 & 2 & 204 \\
\hline 6. & $51-$ and above & 1 & 223 & 1 & 212 \\
\hline
\end{tabular}

Table No. 3: Showing Relation of Serum Cholesterol with the Nature of Work

\begin{tabular}{|l|l|l|l|l|}
\hline Sr. No. & Nature of Work & No. of Cases & Range of S. Cholesterol & $\begin{array}{l}\text { Average Value of S. } \\
\text { Cholesterol }\end{array}$ \\
\hline 1. & Sedentary Work & 12 & $163-241$ & 204 \\
\hline 2. & Moderate Work & 17 & $173-207$ & 189 \\
\hline 3. & Active Work & 11 & $125-217$ & 168 \\
\hline
\end{tabular}

The highest average value $204 \mathrm{mg} \%$ were observed in sedentary individuals ranging between 163-241\% while the lowest value $168 \mathrm{mg} \%$ with range of $125-217 \mathrm{mg} \%$ were observed in individuals with active work.

Table No. 4: Showing Average Value of S. Cholesterol at various interval in relation to age group \& duration of surgical trauma in group $\mathrm{A}(\mathrm{Op}$. within $30 \mathrm{~min}$.)

\begin{tabular}{|l|l|l|l|l|l|l|}
\hline S. No. & Age Group & No. of cases & \multicolumn{4}{|l|}{ Average Value of S. Cholesterol in mo } \\
\hline & & & Pre Operative & $\begin{array}{l}\text { lst Post } \\
\text { Op. Day }\end{array}$ & $\begin{array}{l}\text { Ill Post Op. } \\
\text { Day }\end{array}$ & $\begin{array}{l}\text { Vll Post Op. } \\
\text { Day. }\end{array}$ \\
\hline 1. & $0-12$ & 10 & 149 & 133 & 139 & 147 \\
\hline 2. & $13-20$ & 9 & 163 & 157 & 163 & 168 \\
\hline 3. & $21-30$ & 3 & 197 & 170 & 182 & 194 \\
\hline 4. & $31-40$ & 3 & 205 & 183 & 196 & 200 \\
\hline 5. & $41-50$ & 2 & 187 & 151 & 162 & 188 \\
\hline 6. & $51 \&$ Above & 3 & 202 & 184 & 195 & 203 \\
\hline
\end{tabular}


Serum Cholesterol level was maximum was fall on the first operative day maximally being 4-36 mg \%. The Cholesterol level showed a gradual increase on the $3^{\text {rd }}$ and $7^{\text {rd }}$ post operative day reaching towards the pre operative value on the $7^{\text {st }}$ post operative day.

Table No. 5: Showing Average Value of S. Cholesterol at various interval in relation to age group \& duration of surgical trauma in group $B($ Op. $1 / 2-11 / 2$ hrs)

\begin{tabular}{|c|c|c|c|c|c|c|}
\hline S. No. & Age Group & No. of cases & \multicolumn{4}{|c|}{ Average Value of S. Cholesterol in $\mathrm{mg} \%$} \\
\hline & & & Pre Operative & $\begin{array}{l}\text { lst Post } \\
\text { Op. Day }\end{array}$ & $\begin{array}{l}\text { Ill Post Op. } \\
\text { Day }\end{array}$ & $\begin{array}{l}\text { Vll Post Op. } \\
\text { Day. }\end{array}$ \\
\hline 1. & $0-12$ & 5 & 147 & 120 & 130 & 137 \\
\hline 2. & $13-20$ & 11 & 156 & 130 & 146 & 150 \\
\hline 3. & $21-30$ & 8 & 199 & 176 & 186 & 194 \\
\hline 4. & $31-40$ & 1 & 184 & 168 & 182 & 186 \\
\hline 5. & $41-50$ & 10 & 209 & 180 & 183 & 218 \\
\hline 6. & 51\& Above & 3 & 222 & 197 & 208 & 228 \\
\hline
\end{tabular}

In group $\mathrm{B}$, the cases subjected to surgical stress between $1 / 2-1 \frac{1}{2}$ hours showed a fall in the level of serum cholesterol in all the age groups from $18 \mathrm{mg} \%$ to $54 \%$. The highest fall (54 mg \%) was observed in 21-30 years of age. there initial preoperative values. The serum cholesterol level showed a gradual rise attaining nearly preoperative values on 7 th postoperative day accept in cases between the age group of 21-30 years both whose initial preoperative values much higher as compare to the average values in the control group.

Table No. 6: Showing Average Value of $S$. Cholesterol at various interval in relation to age group \& duration of surgical trauma in group $\mathrm{C}$ ( beyond $1 \frac{1}{2} \mathrm{hrs}$ )

\begin{tabular}{|l|l|l|l|l|l|l|}
\hline S. No. & Age Group & No. of cases & \multicolumn{4}{|l|}{ Average Value of S. Cholesterol in mg \% } \\
\hline & & & Pre Operative & $\begin{array}{l}\text { Ist Post } \\
\text { Op. Day }\end{array}$ & $\begin{array}{l}\text { Ill Post Op. } \\
\text { Day }\end{array}$ & $\begin{array}{l}\text { Vll Post Op. } \\
\text { Day. }\end{array}$ \\
\hline 1. & $0-12$ & 1 & 149 & 111 & 132 & 143 \\
\hline 2. & $13-20$ & 5 & 148 & 121 & 129 & 140 \\
\hline 3. & $21-30$ & 6 & 197 & 157 & 168 & 186 \\
\hline 4. & $31-40$ & 9 & 195 & 158 & 179 & 188 \\
\hline 5. & $41-50$ & 5 & 278 & 207 & 228 & 244 \\
\hline 6. & $51 \&$ Above & 8 & 217 & 165 & 184 & 196 \\
\hline
\end{tabular}

34 cases operated under group $\mathrm{C}$ that is those who were subjected to operative trauma beyond $1 \frac{1}{2} 2$ hours. The fall in serum cholesterol level was maximum on the first operative day ranging. Between $27.71 \mathrm{mg} \%$ in the different age groups however, the maximum fall in the age group between 41-50 years was observed on 1st post operative day.

\section{Discussion}

Stress is the sum total of all non-specific changes caused by function or damage, it is fundamentally a physiological response to stimulus, re-establish the normal state. It includes a variety of adverse conditions, which tend to harm the organisms. It may develop suddenly and be short lasting or develop very gradually and act for long time, or it may be overwhelming ending in death. The effects may be mild or severe.
In the present study of the control group, the Serum Cholesterol level showed a variation in the average values in different age groups. It was observed that with advancing age the Serum Cholesterol level also rises. In our observations the minimum average value of 145 mgm\%, above 51 years of age. Biorck G [1], Dreyfuss [2], stated that plasma cholesterol was low at birth about 50 to $100 \mathrm{mgm} \%$, increasing rapidly within a few days to about 20 to $25 \mathrm{mg}$. below that of the normal 
adult level and this level was maintained till adolescences, between 17 to 30 years, the average cholesterol concentration was raised by about $2 \mathrm{mgm} \%$ per year. Our results are in accordance with these findings, as we have observed a rise of $1.7 \mathrm{mgm} \%$ per year between 21 to 30 years of age. The level continues to increase reaching the maximum in the 6th decade. Frideman M et 1998[3] observed slight increase (16 mgm\%) in the values of the total Serum Cholesterol between the ages of 20-50 years.

The sex had a definite relationship in the serum cholesterol levels. Upto 20 years of age the level was higher in the females while after 21 years of age the level was higher in the females while after 21 years of age the cholesterol level was on a lower side than the males of the same age group. The differences between the level of males and females ranged between 4 to 22 mgm $\%$. In the age groups up to 20 years and beyond 51 years of age the different ranged between 4 to 12 mgm\%. Padmavati reports the difference in the males and females level in different age groups between 2 to 6 mgm\%. The level in the females was low than the males in all age groups. However our observation are not in close proximity to the above cited observations. Much controversial results have been reported in case of fem Lewis set al found that the Serum Cholesterol rose more gradually in women between 20 to 40 years and above this age it continued to rise. Kanter SL 2004 found the mean cholesterol values to be $169 \mathrm{mgm} \%$ for males and $178 \mathrm{mgm} \%$ for females [4].

The difference in the two sexes may be due to the hormonal effect. Testosterone the male sex hormone has no influence on cholesterol metabolism, but female sex hormones, oestrogen and progesterone exert some influence on the plasma cholesterol level. This hormonal influence was the cause of low cholesterol level in females of childbearing age.

Diet and the social status which on the whole affects the dietary intake of an individual has a definite bearing on the Serum Cholesterol level. In our observations the average values for vegetarians and non-vegetarian and 178 and $193 \mathrm{mgm}$ and the individuals with higher social status showed high Serum Cholesterol values as compared to the low social status. The results being 211, 183 and $163 \mathrm{mgm}$ and for higher social status, middle and individuals with low social status respectively. Kellogg F 1999 [5] noted an increase in the Serum Cholesterol with increase in the body weight $\&$ the level of dietary cholesterol concentration [6,7]. Since cholesterol can be synthesized endogenously. Peterson JE 1999 [8], Thomas 2001[9], Wertlake PT 2002 [10]' Desborough 1999 [11] believe that the fat content in the diet may play an important role. It was the habitual fat diet intake rather than the physical activity which influences the concentration of total cholesterol and B lipoprotein in the serum, Appa Rao and his collaborators report that the cholesterol level of vegetarians was higher than that of non-vegetarians. The same was observed in both sexes by Nayak, Nath on the contrary observed that the diet of nonvegetarians had higher caloric values, animal proteins, total fat and proportion of fat derived from animal sources compared to that of vegetarians. They observed significant difference between vegetarians and nonvegetarians and in their study the Serum Cholesterol level was higher in non-vegetarians as compared to vegetarians. This was parallel to our observations.

Jameson P 1999 [12] found higher Serum Cholesterol values in the high socio-economic group of the people as that of the poor community. Findings were again in conjunction to the studies of the above cited workers. This may be due to variety of factors, which affect the diet.

The total caloric intake, the dietary fat content and the physical activity in different socio-economic group and the end results of which may influence the Serum Cholesterol level. Serum Cholesterol level was found to decrease with the rise of activity as observed to be 203 , 188 and $167 \mathrm{mgm} \%$ in sedentary workers respectively. Our observations run in parallel to the work of Mann \& White (1999) [7] who allowed that the concentration of plasma cholesterol was influenced by exercise and stress. Mann has shown that the increase in the blood cholesterol resulting from excessive intake of calories was abolish by exercise.

\section{Conclusion}

The uniform reduction of serum cholesterol observed post operatively could be results of increased utilization and/or decreased formation of cholesterol, and impaired liver function during and following surgery. With the 
increase activity of the individual, the serum cholesterol showed a decrease. The social status of individuals has got a definite bearing on the serum cholesterol level of the individual. Better the social status, higher was the serum cholesterol. Recovery towards the pre-operative value begins after the maximum fall and it was gradual in consecutive post operative days. It was concluded that more the surgical stress slower was the recovery.

Serum cholesterol level was definitely influenced by the type of work the person was engaged in. Amongst active physical workers the fluctuation of serum cholesterol level in post operative period was much less than in patients with sedentary habits.

\section{Funding: Nil,Conflict of interest: None. Permission of IRB: Yes}

\section{References}

1. Biorck G, Blomqvist G, SIEVERS J. Cholesterol values in patients with myocardial infarction and in a normal control group. Acta Med Scand. 1957 Feb 2;156(6):493-7.

2. Dreyfuss F, Czaczkes JW. Blood cholesterol and uric acid of healthy medical students under the stress of an examination. AMA Arch Intern Med. 1959

May;103(5):708-11.

3. Frideman M, Rosenman Rh, Carroll V. Changes in the serum cholesterol and blood clotting time in men subjected to cyclic variation of occupational stress. Circulation. 1958 May;17(5):852-61.

4. Kanter Sl, Goodman Jr, Yarborough J. Determination of free, ester, and total cholesterol without saponification. J Lab Clin Med. 1952 Aug;40(2):30312.

\section{How to cite this article?}

Verma LP, Dutt C, Dutt RD. Effect of surgical stress on Serum cholesterol level. Int J Med Res Rev 2015;3(9):10201025. doi: 10.17511/ijmrr.2015.i9.188.
5. Kellogg F, Goodman JR. Viscosity of blood in myocardial infarction.Circ Res. 1960 Sep;8:972-9.

6. Kyle LH, Hess WC, Walsh WP. The effect of ACTH, cortisone and operative stress upon blood cholesterol levels. J Lab Clin Med. 1952 Apr;39(4):605-17.

7. Man EB, Bettcher PG, Cameron CM, Peters JP. Plasma alpha-amino acid nitrogen and serum lipids of surgical patients. J Clin Invest. 1946 Sep;25(5):701-8.

8. Peterson JE, Wilcox AA, Haley MI, Keith RA. Hourly variation in total serum cholesterol. Circulation. 1960 Aug;22:247-53.

9. Thomas CB, Murphy EA. Further studies on cholesterol levels in the Johns Hopkins medical students: the effect of stress at examinations.J Chronic Dis. 1958 Dec;8(6):661-8.

10. Wertlake PT, Wilcox AA, Haley MI, Peterson JE. Relationship of mental and emotional stress to serum cholesterol levels. Proc Soc Exp Biol Med. 1958 Jan;97(1):163-5.

11. Desborough JP. Physiological responses to surgery and trauma. In: Hemmings HC Jr, Hopkins PM, eds. Foundations of Anaesthesia. London: Mosby, 1999:713-20.

12. Jameson P, Desborough JP, Bryant AE, Hall GM. The effect of cortisol suppression on interleukin6 and white blood cell responses to surgery. Acta Anaesthesiol Scand. 1997 Feb;41(2):304-8. 